Sensors and Actuators B: Chemical

Vol. 120, Issue 1, 14 December 2006, P. 329-337

http://dx.doi.org/10.1016/i.snb.2006.02.024

(c) 2006 Elsevier
Archimer, archive institutionnelle de l'Ifremer http://www.ifremer.fr/docelec/

\title{
In situ QCM DNA-biosensor probe modification
}

\author{
M. Lazerges ${ }^{a}$, H. Perrot ${ }^{a}{ }^{,}$, N. Zeghib ${ }^{a}$, E. Antoine ${ }^{b}$ and C. Compere ${ }^{c}$ \\ aLISE, CNRS-Université Pierre et Marie Curie, 4 Place Jussieu, 75252 Paris Cedex 05, France \\ bIFREMER, Centre de Nantes, rue de l'Ile d'Yeu, BP 21105, 44311 Nantes Cedex 03, France \\ 'IFREMER, Centre de Brest, BP 70, 29280 Plouzané, France \\ *: Corresponding author : perrot@ccr.jussieu.fr
}

\begin{abstract}
:
We report on a probe modification of a quartz crystal microbalance (QCM) DNA-biosensor that permits to reversibly change the DNA sequence detected. A QCM DNA-biosensor was designed by immobilization of a 20-base DNA-disulfide probe on the gold-covered quartz surface of a $27 \mathrm{MHz}$ microbalance $(9 \mathrm{MHz}$, third overtone). After immobilization on the gold covered quartz surface, this probe was modified by hybridization with a 45-base DNA that includes the complementary 20-base sequence, a 5-base spacer and a non-complementary 20-base sequence. The non-complementary sequence constitutes a new probe, different from the DNA-disulfide probe, that permits the detection of a new DNA target. As this 45 bases DNA is changeable by dehybridization, successive different DNA targets can be detected. Kinetics and thermodynamic studies of the DNA-disulfide and modified biosensors indicate that the modified biosensor is as sensitive, selective, fast, renewable and reproducible as the DNA-disulfide biosensor, but with a higher hybridization ratio. This modification method offers wider investigation field and practical and economic advantages to DNA-biosensors based on irreversible immobilization of DNA probes on solid substrate.
\end{abstract}

Keywords: Biosensor; DNA; QCM 


\section{Introduction}

Specific DNA sequence detection is a major issue in life science. An important advance in this field was done during the last two decades with the design of DNA biosensors. They are more efficient by comparison to DNA hybridization tests performed on membranes that are less sensitive, less selective, time consuming and not time resolved [1]. Moreover it has been observed that surface hybridization is faster [2] and more selective [3] than hybridization in bulk solution. DNA biosensors are now intensely developed for diagnostic applications [1,4], environmental monitoring [5] and food controls [6]. The quartz crystal microbalance (QCM), classically based on a thickness shear mode resonator [7], is useful to design DNA-biosensors [8,9,10]. QCM DNA-biosensors are time resolved, enough sensitive to detect non-labelled DNA [9], enough selective to detect single mismatch DNA $[11,12,13]$ renewable [6] and allow multi-analysis [14]. QCM DNA-biosensors have been already used in many fields of human interest: genetic diagnosis [15], detection of genetically modified organisms [6], bacteria detection [16] and toxicology [17]. Moreover, they have been successfully used to investigate various biomolecular mechanisms: DNA surface hybridization kinetics [18], DNA polymerase chain reaction [19,20,21], DNA cleavage reaction [19,22], binding of protein to DNA [23,24,25], evaluation of UV-C DNA damages [26], DNA-drug interactions [17], specific biotinylation of RNA [27] and DNA supramolecular polymerization [28]. QCM DNA-biosensors may be designed by a wide choice of immobilization techniques of short oligonucleotide probe on the quartz microbalance surface. Most of these efficient and more used immobilization techniques are irreversible: chemical adsorption of a DNA labeled with a disulfide or thiol group on gold $[6,20,29,30]$; covalent binding of a DNA labeled with amine on a surface modified with a silane derivative [31,32]; peptide bounding of a DNA labeled with amine on a quartz surface chemically modified with ethylenediamine [33]; formation of a biotin-avidin complex between a DNA labeled with biotin and an avidin modified surface like as copolymer pyrroleavidin film [34], a dextran-avidin layer [35,36] or a thiol-avidin layer $[19,21,24,23]$ and DNA photografting to polystyrene [2]. As these immobilization techniques of the DNA probe on the transducer surface are irreversible, different DNA-biosensors are needed for each different DNA strand. We evaluate in this work a one step in-situ probe replacement procedure to reversibly change the DNA strand targeted by a DNA biosensor designed by an irreversible probe immobilization method. The first step is the immobilization by irreversible adsorption of a 20-base DNA-disulfide probe on a gold-covered quartz surface of a $27 \mathrm{MHz}$ microbalance which as several advantages: the adsorption of the probe by stable bounding between sulfur atom of DNA-disulfide and a gold atom of the surface is irreversible and stable, it takes less than on hour [37] and gold is very stable versus oxidation. This step is followed by the reversible hybridization of a new probe. Both kinetics and thermodynamic behaviors of DNA-disulfide biosensor, before and after modification of the probe on the same transducer, were studied and compared.

\section{Experimental section}

\subsection{Chemical and biochemical reagents}

$\mathrm{H}_{2} \mathrm{SO}_{4}$ 95\%, $\mathrm{H}_{2} \mathrm{O}_{2}$ 30\%, $\mathrm{NaOH}, \mathrm{HCl}, \mathrm{NaCl}, 1 \mathrm{M}$ 2-[4-(2-hydroxyethyl)-1piperazine] ethanesulfonic acid buffer (HEPES) were from Sigma Aldrich. All reagents were of biochemical quality. Water used in all experiments was deionized and double distilled. Lyophilized DNA strands, synthesized by a crosslinked reaction [38], from Eurogentec, were purified by chromatography. Purity was checked by MALDI-TOF analysis and quantification 
was performed by UV optical density measurements. The structure of DNA strands used are presented on the figure 1 . A/ $\underline{A}$ are 20-base complementary sequences as are $\mathrm{B} / \underline{\mathrm{B}}$ and $\mathrm{C} / \underline{\mathrm{C}}$. In the following, three biosensors will be distinguished, according to the DNA probe sequence considered: DNA-disulfide biosensor A and biosensors B and C.

\subsection{Solutions and stringency conditions}

The solvent for DNA immobilization was $0.5 \mathrm{M} \mathrm{NaCl}$ referred to as ' $\mathrm{NaCl}$ '. All hybridization experiments were performed in optimized stringency conditions [29]: $0.05 \mathrm{M}$ HEPES, with $0.5 \mathrm{M} \mathrm{NaCl}$, adjusted to $\mathrm{pH} 7.2$ with drops of $1 \mathrm{M} \mathrm{NaOH}$, referred to as 'HEPES'. The dehybridization solution was $0.5 \mathrm{M} \mathrm{NaOH}$, with $3 \mathrm{M} \mathrm{NaCl}$, referred to as 'NaOH'.

\subsection{QCM apparatus}

The microbalance resonators were Matel-Fordhal France AT-cut planar quartz crystals, $14 \mathrm{~mm}$ in diameter, with a $9 \mathrm{MHz}$ nominal resonance frequency. Two identical gold electrodes, $2000 \AA$ thick and $5 \mathrm{~mm}$ in diameter, were deposited by evaporation techniques on both sides of a quartz with a $250 \AA$ chromium underlayer. Resonator were connected by a silver conducting paste, through wires, to a BNC adaptator. A home-made oscillator was designed to drive the crystal at $27 \mathrm{MHz}$, which corresponds to the third overtone of the quartz resonators. To improve the stability, all the electronic oscillator components were temperature-controlled by a Watlow heater monitor with stability better than $0.1{ }^{\circ} \mathrm{C}$. An experimental cell was developed: the crystal was mounted between two O-ring seals inserted in a plexiglass cell [39]. The gold side of the quartz used in the experiments was cleaned with a $1 / 1 \mathrm{H}_{2} \mathrm{SO}_{4} / \mathrm{H}_{2} \mathrm{O}_{2} 10 \mu \mathrm{L}$ drop for 30 minutes and rinsed with distilled water. The cell volume was $50 \mu \mathrm{L}$. The apparatus included a Pharmacia micropump to assure a $50 \mu \mathrm{L} / \mathrm{min}$ constant flow of the solutions in the QCM cell. Two different quartz were used in this study, referred as quartz 1 and 2. Temperature was controlled at $23^{\circ} \mathrm{C}$ with a thermostat Huber for quartz 1 experiments and was $25 \pm 1^{\circ} \mathrm{C}$ room temperature for quartz 2 experiments. The frequency was computer-controlled by home-made software in $\mathrm{C}$ language and measured with a Fluke PM 6685 frequency counter.

\section{Results}

\section{1 / DNA-disulfide biosensor A}

As illustrated in figure 2, a disulfide-DNA biosensor, referred as A biosensor, was designed by immobilization of a 20-base DNA-disulfide probe $\mathrm{A}$ in $\mathrm{NaCl}$ solution on the gold quartz surface (1). This probe was hybridized in HEPES solution with a complementary DNA target $\underline{A}$ (2) and regenerated by circulation of a $\mathrm{NaOH}$ solution (3) [40]. QCM frequency changes recorded during successive circulation of DNA solutions are presented in figure 3. There is a first $\Delta \mathrm{f}_{\mathrm{A}}=-168 \mathrm{~Hz}$ frequency change during circulation of a $10 \mu \mathrm{g} / \mathrm{mL}$ DNAdisulfide $\mathrm{NaCl}$ solution attributed to chemical adsorption of the DNA-disulfide probe A on the gold surface of the quartz (1). The coverage surface of the QCM gold covered surface with DNA-disulfide probes $\tau$ is estimated to be $69 \%: \tau=\mathrm{S}_{\mathrm{A}} / \mathrm{S}=\left|\Delta \mathrm{f}_{\mathrm{A}}\right| \cdot \mathrm{s}_{\mathrm{QCM}} \cdot \mathcal{N} \cdot \mathrm{s}_{\mathrm{A}} / \mathrm{S} \cdot \mathrm{M}_{\mathrm{A}}$, where $\mathrm{S}=$ $0.2 \mathrm{~cm}^{2}$ is the QCM active surface, $\mathrm{S}_{\mathrm{A}}$ is the QCM active surface covered with DNA-disulfide probes, $\mathrm{s}_{\mathrm{QCM}}=350 \mathrm{pg} / \mathrm{Hz}$ is the $\mathrm{QCM}$ sensitivity [41], $\mathrm{M}_{\mathrm{A}}=6448 \mathrm{~g} / \mathrm{mol}$ is the molecular weight of the DNA-disulfide probe, $\mathrm{s}_{\mathrm{A}}=2.2 \mathrm{~nm}^{2}$ is the average area of one adsorbed DNAdisulfide probe [29] and $\mathcal{N}=6.023 .10^{23} \mathrm{~mol}^{-1}$ is the Avogadro constant. Kinetics of the 
immobilization reaction were estimated by calculating $\Delta t=t^{3} / 4-t^{1 / 4}$, where $t^{3 / 4}$ and $t^{1} 1 / 4$ are respectively the $3 / 4$ and $1 / 4$ reaction time. DNA-disulfide adsorption $\Delta \mathrm{t}$ is equal to $392 \mathrm{~s}$. The next frequency shift is attributed to increase of viscosity and density between $\mathrm{NaCl}$ and HEPES solutions. There is no frequency shift during circulation of $10 \mu \mathrm{g} / \mathrm{mL}$ noncomplementary DNA $\underline{B}$ and DNA $\underline{C}$ HEPES solutions indicating that there is no hybridization or non-specific adsorption of the non-complementary DNA strands $\underline{B}$ and $\underline{C}$. There is a $\Delta \mathrm{f}_{\underline{A}}=$ $-71 \mathrm{~Hz}$ frequency change during circulation of a $10 \mu \mathrm{g} / \mathrm{mL}$ complementary DNA $\underline{\text { A s solution }}$ in HEPES attributed to hybridization of the complementary DNA target $\underline{A}$ with the biosensor DNA probe A (step 2). The corresponding hybridization ratio $\eta$ of hybridized DNA strands $\underline{\mathrm{A}}, \mathrm{N}_{\underline{\mathrm{A}}}$ vs. immobilized DNA-disulfide probes A, $\mathrm{N}_{\mathrm{A}}$ is estimated to be $40 \%: \eta=\mathrm{N}_{\underline{A}} / \mathrm{N}_{\mathrm{A}}=$ $\Delta \mathrm{f}_{\underline{A}} \cdot \mathrm{M}_{\mathrm{A}} / \Delta \mathrm{f}_{\mathrm{A}} \cdot \mathrm{M}_{\underline{A}}$, where $\mathrm{M}_{\underline{A}}=6055 \mathrm{~g} / \mathrm{mol}$ is the molecular weight of the DNA target $\underline{\mathrm{A}}$. The half-time hybridization reaction $\Delta t$ calculated as indicated previously is equal to $85 \mathrm{~s}$. The DNA-disulfide probe was dehybridized by $\mathrm{NaOH}$ circulation for 20 minutes (step 3). This experiment was performed again two times on two different quartz to check the reproducibility. The thermodynamic and kinetic behaviors of biosensors A are compiled on the tables 1 and 2 .

\section{2 / Modified biosensor B}

As shown in figure 4, the DNA-disulfide biosensor A used in the previous study was modified by hybridization in HEPES of the DNA-disulfide probe A with a 45-base DNA $\underline{A}-\mathrm{B}$ that includes a complementary 20 -base sequence $\underline{A}$, a 5-base spacer and a non complementary 20-base sequence B (4). The biosensor B is obtained: the non complementary sequence B constitutes a new DNA probe and offers the possibility of a new hybridization in HEPES with a complementary DNA target $\underline{B}$ (5). The biosensor was regenerated by circulation of a $\mathrm{NaOH}$ solution (6). QCM frequency changes recorded during successive circulation of DNA solutions and solvents are presented on figure 5 . There is a first $\Delta \mathrm{f}_{\underline{A}-\mathrm{B}}=-199 \mathrm{~Hz}$ frequency change during circulation of a $22.5 \mu \mathrm{g} / \mathrm{mL}$ DNA A-B HEPES solution attributed to hybridization of the 45-base DNA $\underline{A}-\mathrm{B}$ with the DNA probe A (4). The corresponding hybridization ratio $\eta$ of hybridized DNA strands $\underline{A}-\mathrm{B}, \mathrm{N}_{\underline{A}-\mathrm{B}} v s$. immobilized DNA-disulfide probe $A, N_{A}$, is estimated to be $45 \%: \eta=N_{\underline{A}-B} / N_{A}=\Delta f_{\underline{A}-B} \cdot M_{A} / \Delta f_{A} \cdot M_{\underline{A}-B}$, where $M_{\underline{A}-B}=13779$ $\mathrm{g} / \mathrm{mol}$ is the molecular weight of the DNA strand $\underline{\mathrm{A}}-\mathrm{B}$. The half-time hybridization reaction $\Delta \mathrm{t}$ calculated as indicated previously is equal to $171 \mathrm{~s}$. There is no frequency shift during circulation of $10 \mu \mathrm{g} / \mathrm{mL}$ non-complementary DNA $\underline{A}$ and $\underline{\mathrm{C}}$ HEPES solutions indicating that there is no hybridization or non-specific adsorption of the non-complementary DNA strands $\underline{\mathrm{A}}$ and $\underline{\mathrm{C}}$. There is a $\Delta \mathrm{f}_{\underline{B}}=-84 \mathrm{~Hz}$ frequency change during circulation of a $10 \mu \mathrm{g} / \mathrm{mL}$ complementary DNA $\underline{B}$ solution in HEPES attributed to hybridization of the DNA target $\underline{B}$ with the DNA strand $\underline{A}-\mathrm{B}$ (5). In this case, the DNA strand $\underline{A}-\mathrm{B}$ constitutes a new probe. The corresponding hybridization ratio $\eta$ of hybridized DNA strands $\underline{B}, \mathrm{~N}_{\underline{B}} v s$. immobilized DNA probes $\underline{A}-\mathrm{B}, \mathrm{N}_{\underline{A}-\mathrm{B}}$, is estimated to be $100 \%: \eta=\mathrm{N}_{\underline{B}} / \mathrm{N}_{\underline{A}-\mathrm{B}}=\Delta \mathrm{f}_{\underline{B}} \cdot \mathrm{M}_{\underline{A}-\mathrm{B}} / \Delta \mathrm{f}_{\underline{A}-\mathrm{B}} \cdot \mathrm{M}_{\underline{B}}$, where $\mathrm{M}_{\underline{B}}=$ $6055 \mathrm{~g} / \mathrm{mol}$ is the molecular weight of the DNA target $\underline{B}$. The half-time hybridization reaction $\Delta \mathrm{t}$ calculated as indicated previously is equal to $110 \mathrm{~s}$. The DNA-disulfide probe was dehybridized by circulation of a $\mathrm{NaOH}$ solution for 20 minutes (6). This experiment was performed again two times to check the reproducibility. The thermodynamic and kinetic behaviors of the modified biosensor B are compiled on the tables 1 and 2 .

\section{3 / Modified biosensor $C$}


The probe modification method was performed to detect a DNA target $\underline{C}$ different from DNA targets $\underline{\mathrm{A}}$ and $\underline{\mathrm{B}}$. The procedure to modify the probe is the same of the probe $\mathrm{B}$ previously described where DNA $\underline{A B}$ is replacing by $\underline{A} C$ and DNA target $\underline{B}$ by $\underline{C}$. The probe $C$ DNA biosensor behavior is exactly the same of probe $B$ behavior as shown on figures 5 and 6. This experiment was performed again three times to check the reproducibility. The thermodynamic and kinetic behaviors of these probe C DNA-biosensors are compiled on the tables 1 and 2 .

\section{4 / Regeneration}

The DNA-disulfide monolayer adsorbed on the gold quartz surface is more resilient than the transducer: after 1 from 2 month of intensive use, corresponding to more than 100 runs, the piezoelectric quartz sealed in the plexiglass cell loses its resonance accuracy. It induces dissipation of acoustic wavelength and frequency measurements can not be more done.

\section{4 / Discussion}

\section{1 / Correlation of QCM frequency changes with mass changes}

The linear correlation between frequency and mass change of the QCM, $\Delta \mathrm{f}=-\mathrm{s} . \Delta \mathrm{M}$, where s depend on the piezoelectric quartz oscillator used, was first established by Sauerbey [7]. This equation permits determination of quantitative mass changes of the quartz by measuring frequency changes. Sauerbey law is not valid when the mass increase is too important and more specially for deposition on the quartz surface of soft organic chemical or biochemical films. Nevertheless, even if there is a viscoelastic energy dissipation, it has been found that it is possible to correlate linearly relative frequency and mass changes for DNA strands below 450 bases [28]. DNA strands grafted on the quartz surface studied in this work do not exceed 45-base, and so quartz mass changes can be correlated to relative quartz frequency changes. In the experiments presented in this work, the experimental proof that relative frequency changes with mass are linear is that the mean ratio value between frequency change during hybridization of 45-base DNAs and 20-base DNAs is close to the ratio between the number of base pair: $\Delta \mathrm{f}_{45 \text {-base }} / \Delta_{\mathrm{f} 20 \text {-base }}=2.38$ and $45 / 20=2.25$. The frequency change during adsorption of DNA-disulfide probe A was used to estimated surface coverage of the gold coated quartz. This surface coverage value is an estimation, because active surface of the QCM, QCM experimental sensitivity and the molecular surface of the DNA-probe are not known with accuracy. Moreover it is overestimated because we do not take in account trap solvent effects [42]. The frequency change during hybridization of the classic biosensor A and the modified biosensor B were used to estimated the hybridization ratios. By comparison with the coverage surface, the hybridization ratio is calculated with accuracy: hybridization ratio does not take in account the active surface of the QCM and the molecular surface of the DNA-probe, the possible error done on the QCM sensitivity is no more done because it vanishes in the ratio. Moreover water trap effects are minimized: assuming that this effect is proportional to the amount of DNA grafted on the QCM surface, it will vanish in the ratio. The adsorption and hybridization reaction half-times are estimated with accuracy, according to the step time of frequency record which is in the second scale by comparison to adsorption and hybridization phenomena which are in the minute scale. The efficiency of the three biosensors will be discussed by comparison of hybridization ratios and reaction half-times which are determinate with accuracy. 


\section{2 / Comparison of DNA-disulfide biosensor A with modified biosensors B and C}

The behaviors of the probe A, B and C DNA-biosensors compiled in the tables 1,2 and 3 will be discussed. Probe A and B DNA-biosensors were designed on two quartz, referred as quartz 1 and 2. Probe C DNA-biosensor was designed on the quartz 2.

\subsection{1 / DNA-disulfide biosensor A}

First of all, the probe A biosensor designed on quartz 1 was selective, as there is no frequency change of the QCM during circulation of the non complementary DNA $\underline{B}$ and $\underline{C}$ HEPES solutions. This acoustic biosensor was sensitive, there was a $-71 \mathrm{~Hz}$ frequency change

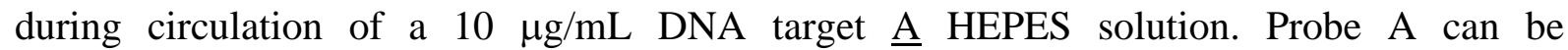
dehybridized by circulation of a $\mathrm{NaOH}$ solution and hybridized again with the complementary DNA target $\underline{A}$. The frequency changes measured during successive hybridization cycles of the probe A were $-60,-71$ and $-69 \mathrm{~Hz}$, indicating that the biosensor is renewable and reproducible. Mean sensitivity value were $-67 \pm 6 \mathrm{~Hz}$, the corresponding mean hybridization ratio value $38 \pm 3 \%$ and the mean $\Delta$ t time response $109 \pm 21 \mathrm{~s}$. Three hybridization cycles were performed on an other probe A biosensor designed on the quartz 2. The results shown on table 1,2 and 3 indicate that the behaviors of DNA probe A biosensors designed on quartz 1 and 2 are close. Sensitivity $\Delta \mathrm{f}$, hybridization ratio $\eta$ and time response $\Delta \mathrm{t}$ are consistent with values found in the literature for DNA disulfide monolayers with similar DNA length, DNA concentration and stringency conditions which are $\Delta \mathrm{f}=-77 \mathrm{~Hz}, \eta=47 \%$ [29] or $\eta=48 \%$ [40] and $\Delta \mathrm{t}=80 \mathrm{~s}$ [43].

\subsection{2 / Modified biosensor B}

The probe B biosensor was designed by hybridization of DNA-disulfide probe A with the 45-base DNA strand $\underline{A}-\mathrm{B}$. It was selective, there was no frequency change of the QCM during circulation of the non complementary DNA $\underline{A}$ and $\underline{C}$ HEPES solutions. It was sensitive, there is a $-84 \mathrm{~Hz}$ frequency change during circulation of the complementary DNA target $\underline{B}$ HEPES solution. DNA-disulfide probe A can be dehybridized by circulation of a $\mathrm{NaOH}$ solution and hybridized again with DNA strands $\underline{\mathrm{A}}-\mathrm{B}$ and $\underline{\mathrm{B}}$. The frequency changes measured during successive hybridization cycles of the probe B were $-82,-84$ and $-83 \mathrm{~Hz}$, indicating that the biosensor is renewable and reproducible. The mean sensitivity value of the acoustic sensor was $-83 \pm 1 \mathrm{~Hz}$, the corresponding mean hybridization ratio value is $91 \pm 8 \%$ and the mean $\Delta \mathrm{t}$ time response is $102 \pm 8 \mathrm{~s}$. Comparative behaviors of probe $\mathrm{A}$ and $\mathrm{B}$ are summarized in the table 3 . The modified probe $\mathrm{B}$ biosensor was as selective as the probe $\mathrm{A}$ biosensor: crossing hybridization experiments indicate that there was no hybridization of the DNA $\underline{B}$, which was the target of the probe $\mathrm{B}$ biosensor, on the probe A biosensor, and, reciprocally, there was no hybridization of the DNA $\underline{A}$, which was the target of the biosensor probe A biosensor, on the probe B biosensor. The probe B biosensor sensitivity was higher than probe A sensitivity: the frequency mean value change was $-67 \pm 6 \mathrm{~Hz}$ during DNA target

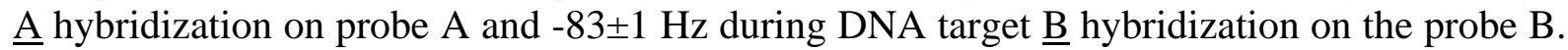
The probe $\mathrm{B}$ biosensor has an hybridization close to $100 \%$ and two times higher than the probe A biosensor: the hybridization ratio was $91 \pm 8 \%$ on the probe A and $-38 \pm 3 \mathrm{~Hz}$ during hybridization on the probe $\mathrm{B}$. The higher hybridization ratio for the modified probe $\mathrm{B}$ is consistent with the behavior of a diluted DNA monolayer which values are from $75 \%$ to $90 \%$ [43]. Hybridization of a diluted DNA layer is enhanced by diminution of repulsive interaction between negatively charged DNA strands. The A-B DNA probe layer of the probe $B$ biosensor is diluted by comparison with the probe $\mathrm{A}$ biosensor: the ratio of DNA probes $\underline{A} B$ 
vs. DNA probes $\mathrm{A}, \mathrm{N}_{\underline{\mathrm{A}}-\mathrm{B}} / \mathrm{N}_{\underline{B}}=\Delta \mathrm{f}_{\underline{A}-\mathrm{B}} \cdot \mathrm{M}_{\underline{B}} / \Delta \mathrm{f}_{\underline{B}} \cdot \mathrm{M}_{\underline{A}-\mathrm{B}}$, is 0.46 . It means that there was two times less probes on the biosensor $\mathrm{B}$ than on the biosensor $\mathrm{A}$. The time response of the two biosensors were close, $109 \pm 21 \mathrm{~s}$ for the biosensor A and $102 \pm 8 \mathrm{~s}$ for the biosensor B. Probe A and B DNA biosensor designed on the quartz 2 had similar behaviors, as shown on tables 1, 2 and 3 , indicating that the proposed method is reproducible.

\subsection{3 / Modified biosensor C.}

To prove that the proposed probe modification method is general, we design on the quartz 1 a DNA-biosensor, referred as $\mathrm{C}$, to detect a DNA sequence $\underline{\mathrm{C}}$, different from DNA target of the modified biosensor $\mathrm{B}$. The behavior of this new probe $\mathrm{C}$ is very close to the behavior of the modified probe $\mathrm{B}$, as shown on figures 5 and 6 . Thermodynamic and kinetics parameters of probes $\mathrm{B}$ and $\mathrm{C}$ summarized in tables 3 are very close.

\section{Conclusion}

We evaluate in this study a one step in-situ probe modification of a QCM DNAbiosensor that permits to reversibly change the sequence detected by a DNA-disulfide biosensor. The modified probe was as selective, sensitive, renewable, fast and reproducible as the original, but with a higher hybridization ratio. The reversibility of the probe modification with a non-labeled DNA strand by keeping the same transducer afford wider investigation field, and practical and economic advantages to QCM DNA biosensors based on irreversible immobilization of DNA probes on solid substrates. By this way, it will be possible to do DNA multidetection in the same run by using a single gravimetric transducer.

\section{Acknowledgements}

We wish to thank the French Ministry of Research for its financial support (ACI CAPALEX), Dr. John S. Lomas and Elisabeth Briand for fruitful discussions. 


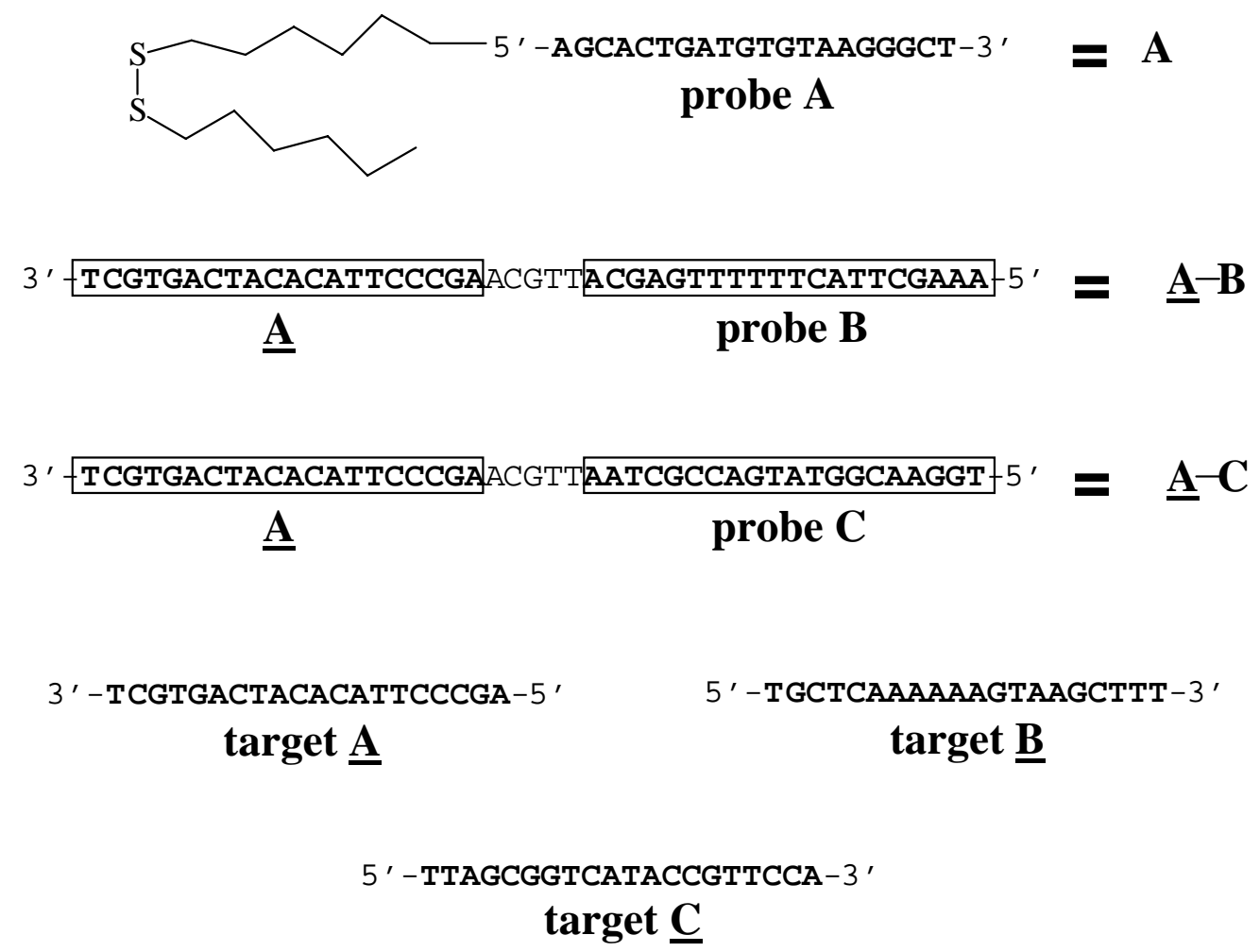

Fig. 1. DNA strands structures 


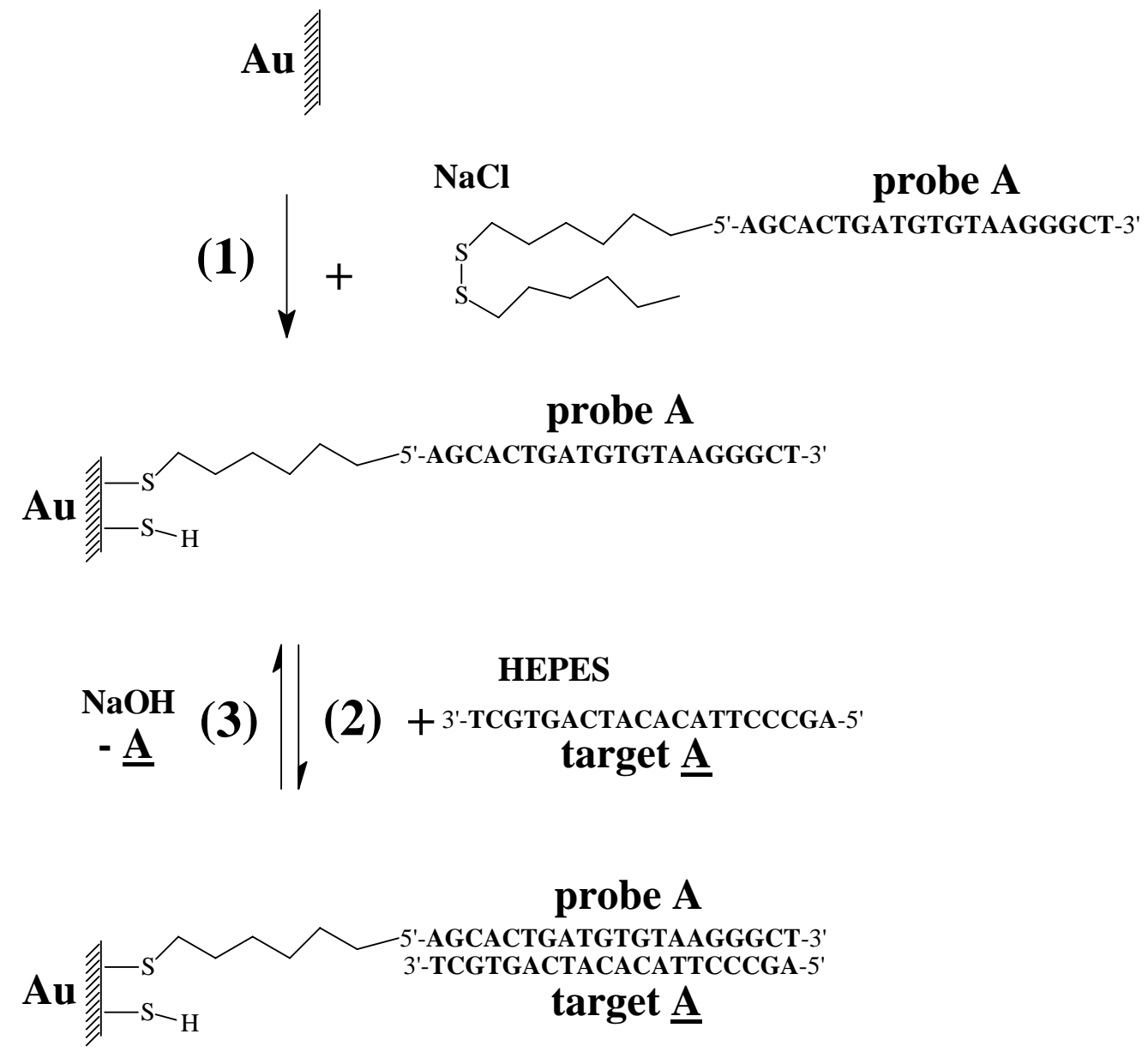

Fig. 2. DNA-disulfide biosensor A biosensor: immobilization of DNA-disulfide probe A (1), hybridization of a complementary DNA target $\underline{A}$ (2) and dehybridization of the DNA target $\underline{A}$ (3). 


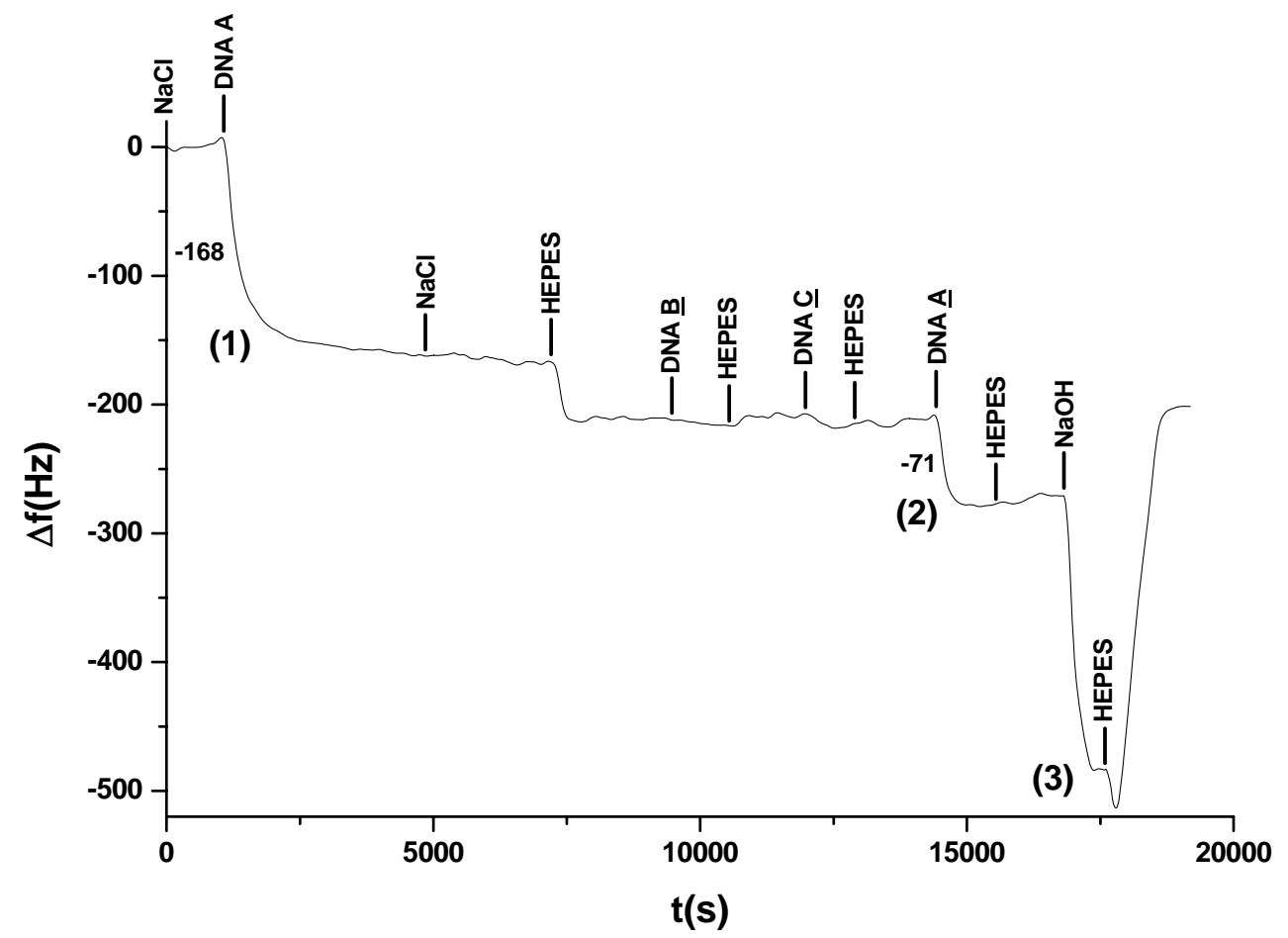

Fig. 3. DNA-disulfide biosensor A: QCM frequency changes during successive circulation of $10 \mu \mathrm{g} / \mathrm{mL} \mathrm{DNA}$ disulfide probe A NaCl solution (1), $10 \mu \mathrm{g} / \mathrm{mL}$ DNA target B HEPES solution, $10 \mu \mathrm{g} / \mathrm{mL}$ DNA target $\underline{\mathrm{C}}$ HEPES solution, $10 \mu \mathrm{g} / \mathrm{mL}$ DNA target $\underline{\mathrm{A}} \mathrm{HEPES}$ solution (2) and $\mathrm{NaOH}$ solution (3). 
A

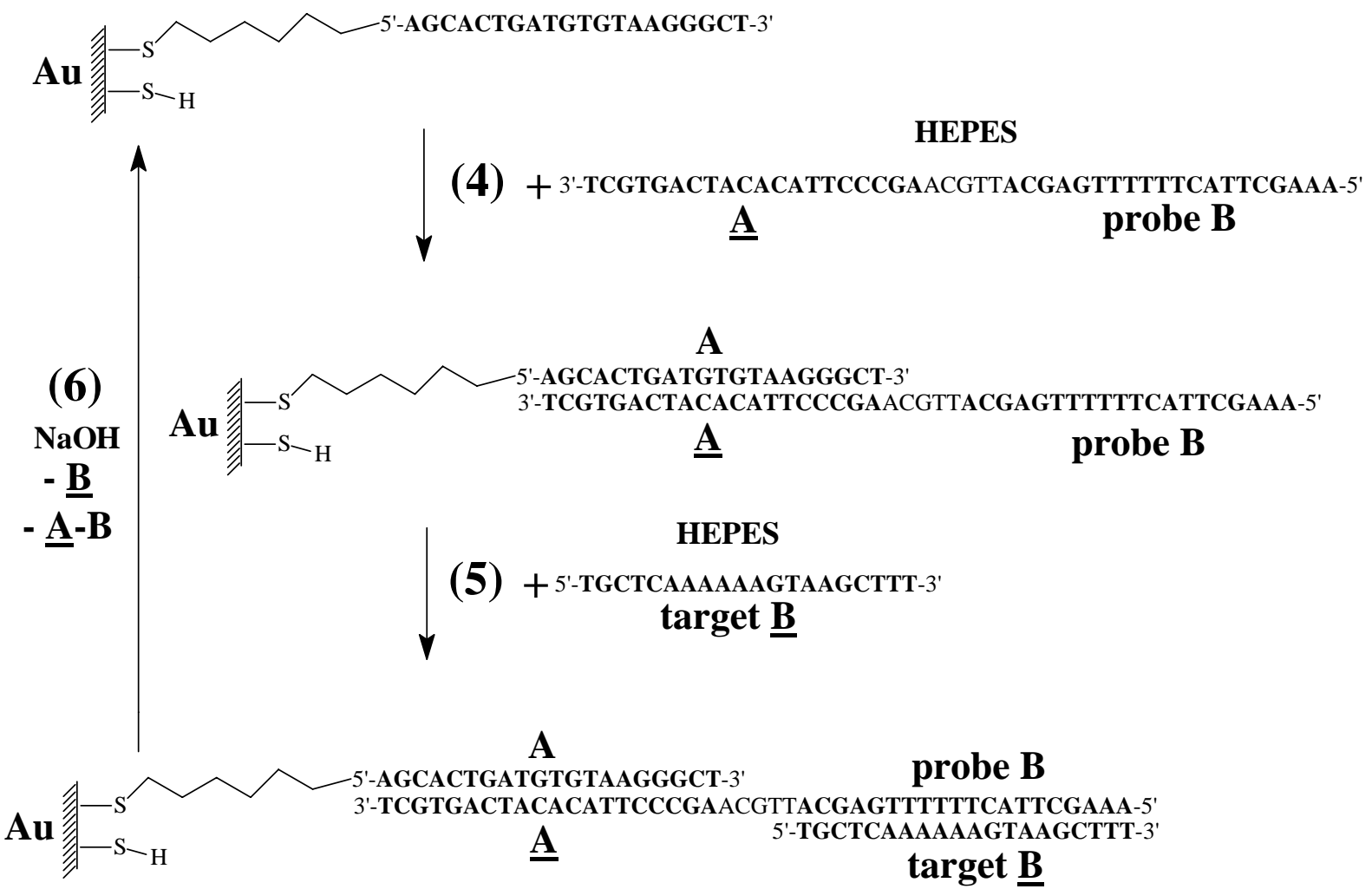

Fig. 4. Modified biosensor B: immobilization of DNA-disulfide probe B (4), hybridization of a complementary DNA target $\underline{B}$ (5) and dehybridization of the DNA target $\underline{B}$ (6). 


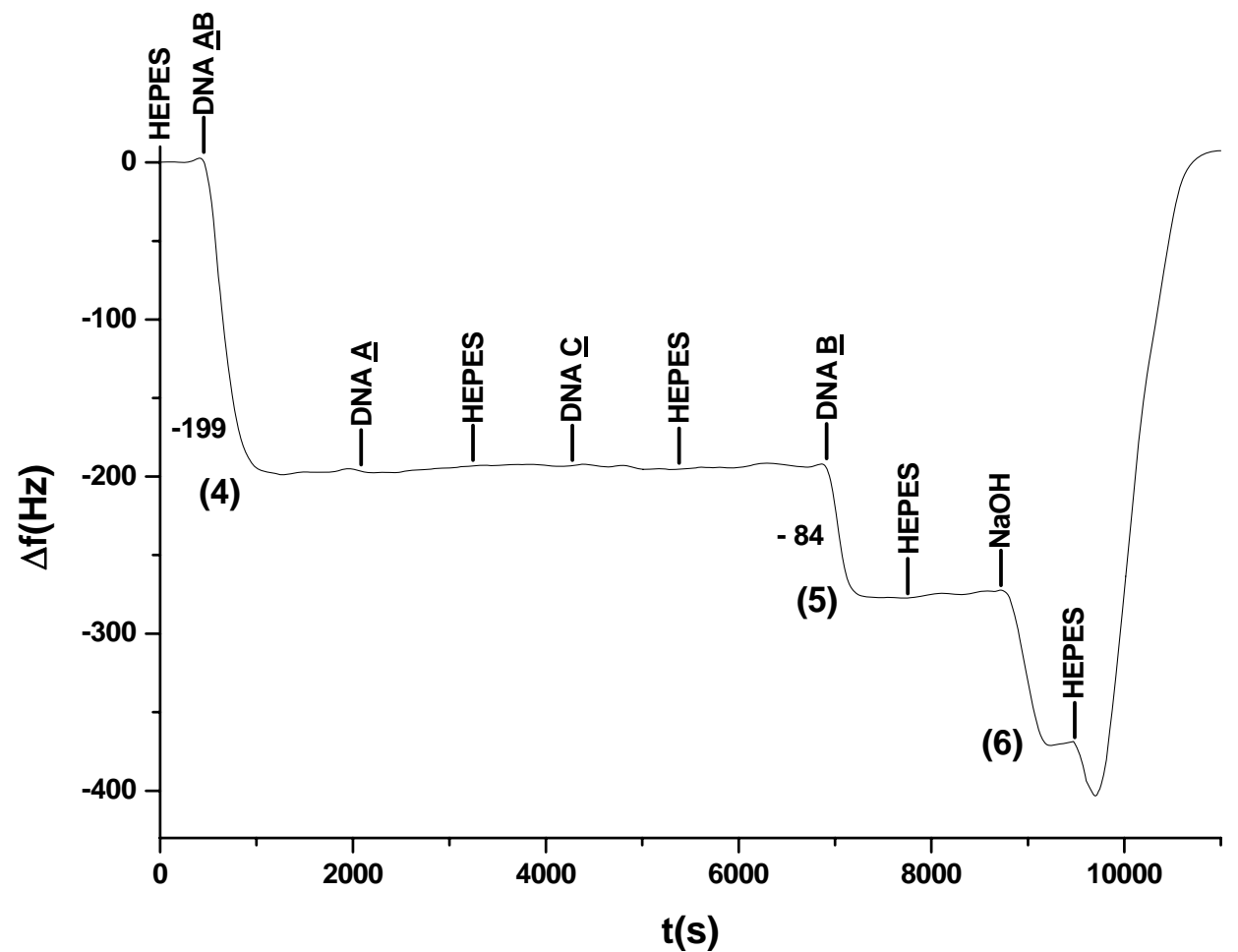

Fig. 5. Modified biosensor B: QCM frequency changes during successive circulation of $22.5 \mu \mathrm{g} / \mathrm{mL}$ DNA probe $\underline{A B}$ HEPES solution (4), $10 \mu \mathrm{g} / \mathrm{mL}$ DNA target $\underline{A}$ HEPES solution, $10 \mu \mathrm{g} / \mathrm{mL}$ DNA target $\underline{C}$ HEPES solution, $10 \mu \mathrm{g} / \mathrm{mL}$ DNA target $\underline{B}$ HEPES solution (5) and $\mathrm{NaOH}$ solution (6). 


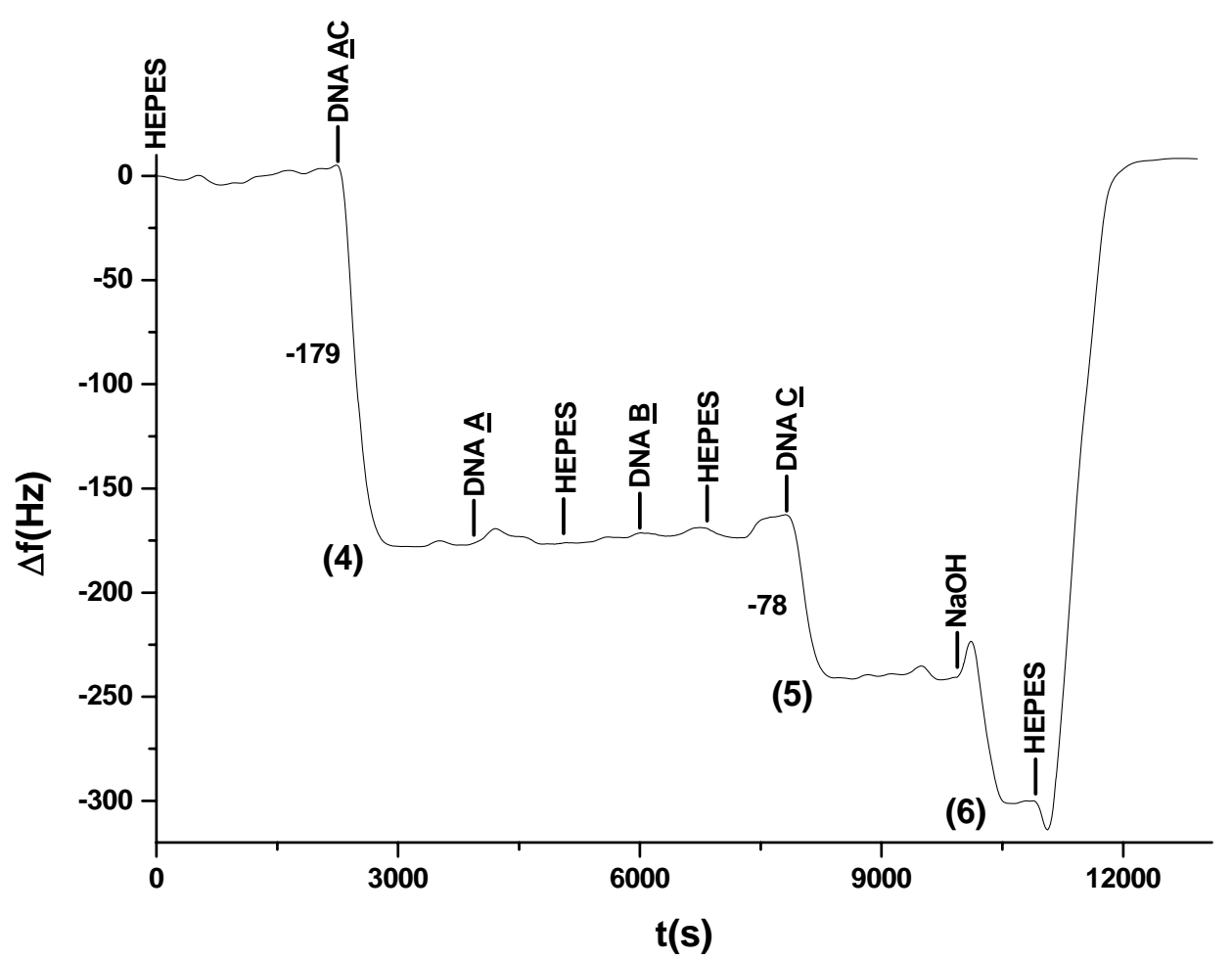

Fig. 6. Modified biosensor C: QCM frequency changes during successive circulation of $22.5 \mu \mathrm{g} / \mathrm{mL}$ DNA probe

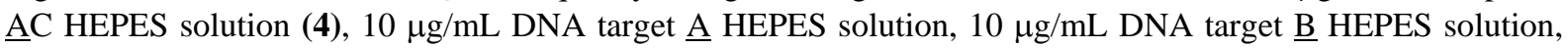
$10 \mu \mathrm{g} / \mathrm{mL}$ DNA target $\underline{\mathrm{C}}$ HEPES solution (5) and $\mathrm{NaOH}$ solution (6). 


\begin{tabular}{|c|c|c|c|c|c|c|}
\hline $\begin{array}{c}\text { biosensors } \\
\text { quartz } 1\end{array}$ & run & $\begin{array}{c}\Delta \mathbf{f}(\mathbf{H z}) \\
\text { probe }\end{array}$ & $\begin{array}{c}\Delta \mathbf{f}(\mathrm{Hz}) \\
\text { target } \mathrm{A}\end{array}$ & $\begin{array}{c}\Delta \mathbf{f}(\mathrm{Hz}) \\
\text { target } \underline{B}\end{array}$ & $\begin{array}{c}\Delta \mathbf{f}(\mathrm{Hz}) \\
\text { target } \underline{\mathrm{C}}\end{array}$ & $\begin{array}{c}\text { hybridization } \\
\text { ratio } \eta(\%)\end{array}$ \\
\hline \multirow{4}{*}{$\begin{array}{c}\text { classic } \\
\text { probe A }\end{array}$} & 1 & \multirow{3}{*}{168} & 60 & 0 & 0 & 34 \\
\hline & 2 & & 71 & 0 & 0 & 40 \\
\hline & 3 & & 69 & 0 & 0 & 39 \\
\hline & mean & 168 & $67 \pm 6$ & 0 & 0 & $38 \pm 3$ \\
\hline \multirow{4}{*}{$\begin{array}{c}\text { modified } \\
\text { probe B }\end{array}$} & 1 & 205 & 0 & 82 & 0 & 85 \\
\hline & 2 & 179 & 0 & 84 & 0 & 100 \\
\hline & 3 & 204 & 0 & 84 & 0 & 88 \\
\hline & mean & $196 \pm 15$ & 0 & $83 \pm 1$ & 0 & $91 \pm 8$ \\
\hline \multirow{4}{*}{$\begin{array}{l}\text { modified } \\
\text { probe } C\end{array}$} & 1 & 179 & 0 & 0 & 86 & 98 \\
\hline & 2 & 172 & 0 & 0 & 78 & 96 \\
\hline & 3 & 172 & 0 & 0 & 81 & 104 \\
\hline & mean & $182 \pm 12$ & 0 & 0 & $82 \pm 4$ & $99 \pm 4$ \\
\hline $\begin{array}{c}\text { biosensors } \\
\text { quartz } 2\end{array}$ & run & $\begin{array}{l}\Delta \mathbf{f}(\mathbf{H z}) \\
\text { probe }\end{array}$ & $\begin{array}{c}\Delta \mathbf{f}(\mathbf{H z}) \underline{\mathrm{A}} \\
\text { target }\end{array}$ & $\begin{array}{c}\Delta \mathbf{f}(\mathbf{H z}) \underline{B} \\
\text { target }\end{array}$ & & $\begin{array}{c}\text { hybridization } \\
\text { ratio } \eta(\%)\end{array}$ \\
\hline \multirow{4}{*}{$\begin{array}{c}\text { classic } \\
\text { probe } A\end{array}$} & 1 & \multirow{3}{*}{204} & 65 & 0 & & 34 \\
\hline & 2 & & 65 & 0 & & 34 \\
\hline & 3 & & 60 & 0 & & 31 \\
\hline & mean & 204 & $63 \pm 3$ & 0 & & $33 \pm 2$ \\
\hline \multirow{4}{*}{$\begin{array}{c}\text { modified } \\
\text { probe B }\end{array}$} & 1 & 184 & 0 & 65 & & 80 \\
\hline & 2 & 159 & 0 & 61 & & 87 \\
\hline & 3 & 180 & 0 & 69 & & 87 \\
\hline & mean & $174 \pm 13$ & 0 & $65 \pm 4$ & & $85 \pm 4$ \\
\hline
\end{tabular}

Table 1. Thermodynamic biosensors behaviors on two different quartz. 


\begin{tabular}{|c|c|c|c|}
\hline $\begin{array}{c}\text { biosensors } \\
\text { quartz } 1\end{array}$ & run & $\Delta \mathrm{t}(\mathrm{s})$ probe & $\Delta \mathrm{t}(\mathrm{s})$ target \\
\hline \multirow{4}{*}{$\begin{array}{c}\text { classic } \\
\text { probe A }\end{array}$} & 1 & \multirow[t]{3}{*}{392} & 120 \\
\hline & 2 & & 85 \\
\hline & 3 & & 121 \\
\hline & mean & 392 & $109 \pm 21$ \\
\hline \multirow{4}{*}{$\begin{array}{l}\text { modified } \\
\text { probe B }\end{array}$} & 1 & 211 & 100 \\
\hline & 2 & 171 & 110 \\
\hline & 3 & 115 & 95 \\
\hline & mean & $166 \pm 28$ & $102 \pm 8$ \\
\hline \multirow{4}{*}{$\begin{array}{l}\text { modified } \\
\text { probe C }\end{array}$} & 1 & 161 & 161 \\
\hline & 2 & 170 & 150 \\
\hline & 3 & 140 & 111 \\
\hline & mean & $157 \pm 15$ & $141 \pm 26$ \\
\hline $\begin{array}{c}\text { biosensors } \\
\text { quartz } 2\end{array}$ & run & $\Delta t(s)$ probe & $\Delta \mathrm{t}(\mathrm{s})$ target \\
\hline \multirow{4}{*}{$\begin{array}{c}\text { classic } \\
\text { probe A }\end{array}$} & 1 & \multirow{3}{*}{334} & 114 \\
\hline & 2 & & 135 \\
\hline & 3 & & 94 \\
\hline & mean & 334 & $114 \pm 21$ \\
\hline \multirow{4}{*}{$\begin{array}{l}\text { modified } \\
\text { probe B }\end{array}$} & 1 & 151 & 116 \\
\hline & 2 & 132 & 149 \\
\hline & 3 & 151 & 106 \\
\hline & mean & $145 \pm 11$ & $124 \pm 23$ \\
\hline
\end{tabular}

Table 2. Kinetic biosensors behaviors on two different quartz. 


\begin{tabular}{|c|c|c|c|}
\hline biosensors quartz 1 & probe $A$ & probe $B$ & probe $\mathrm{C}$ \\
\hline sensitivity $\Delta \mathrm{f}_{\mathrm{A}}(\mathrm{Hz})$ & $67 \pm 6$ & 0 & 0 \\
\hline sensitivity $\Delta \mathrm{f}_{\mathrm{B}}(\mathrm{Hz})$ & 0 & $83 \pm 1$ & 0 \\
\hline sensitivity $\Delta \mathrm{f}_{\mathrm{C}}(\mathrm{Hz})$ & 0 & 0 & $82 \pm 4$ \\
\hline hybridization ratio $\tau(\%)$ & $38 \pm 3$ & $91 \pm 8$ & $99 \pm 4$ \\
\hline time response $\Delta \mathrm{t}(\mathrm{s})$ & $109 \pm 21$ & $102 \pm 8$ & $141 \pm 26$ \\
\hline biosensors quartz 2 & probe $A$ & probe $B$ & \\
\hline sensitivity $\Delta \mathrm{f}_{\mathrm{A}}(\mathrm{Hz})$ & $63 \pm 3$ & 0 & \\
\hline sensitivity $\Delta \mathrm{f}_{\mathrm{B}}(\mathrm{Hz})$ & 0 & $65 \pm 4$ & \\
\hline hybridization ratio $\tau(\%)$ & $33 \pm 2$ & $85 \pm 4$ & \\
\hline time response $\Delta \mathrm{t}(\mathrm{s})$ & $114 \pm 21$ & $124 \pm 23$ & \\
\hline
\end{tabular}

Table 3. Comparative biosensors behaviors on two different quartz.

[1] M. Campàs, I. Katakis, DNA biochip arraying, detection and amplification strategies, Trends in Analytical Chemistry 23 (2004) 49-62.

[2] R. B. Towery, N. C. Fawcett, P. Zhang, J. A. Evans, Genomic DNA hybridizes with the same rate constant on the QCM biosensor as in homogeneous solution, Biosens. Bioelectron. 16 (2001) 1-8.

[3] J. Watterson, P. A. E. Piunno, U. J. Krull, Pratical physical aspects of interfacial nucleic acid oligomer hybridization for biosensor design, Analytica Chimica Acta 469 (2002) 115-127.

[4] J. Wang, From DNA biosensors to gene chips, Nucleic Acid Research 28 (2000) 3011-3016.

[5] S. Rodriguez-Mozaz, M. J. López de Alda, M.-P. Marco, D. Barceló, Biosensors for environmental monitoring A global perspective, Talanta 65 (2005) 291-297.

[6] I. Mannelli, M. Minunni, S. Tombelli, M. Mascini, Quartz crystal microbalance (QCM) affinity biosensor for genetically modified organism (GMOs) detection, Biosens. Bioelectron. 18 (2003) 129-140.

[7] G. Sauerbrey, Verwendung von Schwingquarzen zur Wägung dünner Schichten und zur Mirkowägung, Z. Phys, 155 (1959) 206-222.

[8] N. C. Fawcett, J. A. Evans, L. Chien, N. Flowers, Nucleic-acid hybridization detected by piezoelectric resonance, Anal. Lett. 21 (1988) 1099-1114.

[9] Y. Okahata, Y. Matsunobu, K. Ijiro, M. Mukae, A. Murakami, K. Makino, Hybridization of nucleic acids immobilized on a quartz crystal microbalance, J. Am. Chem. Soc. 114 (1992) 8299-8300.

[10] S. Yamaguchi, T. Shimomura, T. Tatsuma, N. Shimomura, Adsorption, immobilization and hybridization of DNA studied by the use of quartz crystal oscillators, Anal. Chem. 65 (1993) 1925-1927.

[11] F. Höök, A. Ray, B. Nordén; B. Kasemo, Characterization of PNA and DNA immobilization and subsequent hybridization with DNA using acoustic-shear-wave attenuation measurements, Langmuir 17 (2001) 8305-8312.

[12] I. Willner, F. Patolsky, Y. Weizmann, B. Willner, Amplified detection of single-base mismatches in DNA using microgravimetric quartz-crystal-microbalance transduction, Talanta 56 (2002) 847-856.

[13] K. Tawa, W. Knoll, Mismatching base-pair dependence of the kinetics of DNA-DNA hybridization studied by surface plasmon fluorescence spectroscopy, Nucleic Acid Research 32 (2004) 2372-2377.

[14] F. Weiling, W. Jianghua, L. Minghua, W. Yingying, Combinatorial and automatic detection method of target gene, and a detector using the method (2001) Patent WO013667.

[15] A. Bardea, A. Dagan, I. Ben-Dov, B. Amit, Amplified microgravimetric quartz-crystal-microbalance analyses of oligonucleotide complexes: a route to a Tay-Sachs biosensor device, Chem. Commun. (1998) 839840.

[16] X.-T. Mo, Y.-P. Zhou, H. Lei, L. Deng, Microbalance-DNA probe method for the detection of specific bacteria in water, Enzyme and Microbial Technology 30 (2002) 583-589.

[17]L. H. Pope, S. Allen, M. C. Davies, C. J. Roberts, S. J. B. Tendler, P. M. Williams, Probing DNA Duplex Formation and DNA-Drug Interactions by the Quartz Crystal Microbalance Technique, Langmuir 17 (2001) 8300-8304.

[18] H. Su, M. Thompson, Kinetics of interfacial nucleic acid hybridization studied by acoustic network analysis, Biosens. Bioelectron. 10 (1995) 329-340.

[19] K. Niikura, H. Matsuno, Y. Okahata, Direct monitoring of DNA polymerase reactions on a quartz-crystal microbalance, J. Am. Chem. Soc. 120 (1998) 8537-8538. 
[20] I. Mannelli, M. Minunni, S. Tombelli, R. Wang, M. M. Spiriti, M. Mascini, Direct immobilization of DNA probes for the development of affinity biosensors, Bioelectrochem. 66 (2005) 129-138.

[21] G. Stengel, F. Höök, W. Knoll, Viscoelastic modeling of template-directed DNA synthesis, Anal. Chem 77 (2005) 3709-3714.

[22] H. Matsuno, H. Furusawa, Y. Okahata, Kinetic Studies of DNA Cleavage Reactions Catalyzed by an ATPDependent Deoxyribonuclease on a 27-MHz Quartz-Crystal Microbalance, Biochemistry 44 (2005) 2262-2270.

[23] Y. Okahata, K. Niikura, Y. Sugiura, M. Sawada, T. Morii, Kinetic studies of sequence-specific binding of GCN4-bZIP peptides to DNA strands immobilized on a 27-MHz quartz-crystal microbalance, Biochemistry 37 (1998) 5666-5672.

[24] X. Su, R. Robelek, Y. Wu, G. Wang, W. Knoll, Detection of point mutation and insertion mutations in DNA using a quartz crystal microbalance and MutS, a mismatch ninding protein, Anal. Chem. 76 (2004) 489-494.

[25] T. Hianik, V. Ostatná, Z. Zajacová, The study of the binding of globular proteins to DNA using mass detection and electrochemical indicator methods, J. Electroanal. Chem. 564 (2004) 19-24.

[26] H. Zhang, H. Tan, R. Wang, W. Wei, S. Yao, Immobilization of DNA on silver surface of bulk acoustic wave sensor and its application to the study of UV-C damage, Analytica Chimica Acta 374 (1998) 31-38.

[27] K. Moriyama, M. Kimoto, T. Mitsui, S. Yokoyama, I. Hirao, Site-specific biotinylation of RNA molecules by transcription using unnatural base pairs, Nucleic Acid Research, 33 (2005) e129, doi:10.1093/nar/gni128.

[28] M. Lazerges, H. Perrot, R. Niriniony, E. Antoine, C. Compere, 45- and 70-Base DNA supramolecular polymerizations on quartz microbalance biosensor (2005) 6020-6022.

[29] C. X. Zhou, L. Q. Huang, S. F. Y. Li, Microgravimetric DNA sensor based on quartz crystal microbalance: comparison of oligonucleotide immobilization methods and the application in genetic diagnosis, Biosens. Bioelectron. 16 (2001) 85-95.

[30] T. H. Ha, S. Kim, G. Lim, K. Kim, Influence of liquid medium and surface morphology on the response of QCM during immobilization and hybridization of short oligonucleotides, Biosens. Bioelectron. 20 (2004) 378389.

[31] T. C. Hang, A. Guiseppi-Elie, Frequency dependent and surface characterization of DNA immobilization and hybridization, Biosens. Bioelectron. 19 (2004) 1537-1548.

[32] M. Gheorghe, A. Guiseppi-Elie, Electrical frequency dependent characterization of DNA hybridization, Biosens. Bioelectron. 19 (2003) 95-102.

[33] M. Duman, R. Saber, E. Pişkin, A new approach for immobilization of oligonucleotides onto piezoelectric quartz crystal for preparation of a nucleic acid sensor for following hybridization, Biosens. Bioelectron. 18 (2003) 1355-1363.

[34] A. Dupont-Filliard, M. Billon, T. Livache, S. Guillerez, Biotin/avidin system for the generation of fully renewable DNA sensor based on biotinylated polypyrrole film, Analytica Chimica Acta 515 (2004) 271-277.

[35] S. Storri, T. Santoni, M. Mascini, A piezzoelctric biosensor for DNA hybridization reaction, Analytical Letters 31 (1998) 1795-1808

[36] S. Tombelli, M. Mascini, L. Braccini, M. Anichini, A. P. F. Turner, Coupling of a DNA piezoelectric biosensor and polymerase chain reaction to detect apolipoprotein E polymorphisms, Biosens. Bioelectron. 15 (2000) 363-370.

[37] E. Huang, M. Satjapipat, S. Han, F. Zhou, F, Langmuir, 17 (2001) 1215-1224.

[38] A. Atsushi, M. Akira, Production of Oligonucleotide Probe, Patent (1990) 63-19-1087.

[39] K. Bizet, C. Gabrielli, H. Perrot, J. Therasse, Validation of antibody-based recognition by piezzoelectric transducers through electroacoustic admittance analysis, Biosens. Bioelectron. 13 (1998) 259-269.

[40] M. Lazerges, H. Perrot, E. Antoine, A. Defontaine, C. Compere, Oligonucleotide quartz crystal microbalance sensor for the microalgae Alexandrium minutum (Dinophyceae), Biosens. Bioelectron 21 (2006) 1355-1358.

[41] K. Bizet, C. Gabrielli, H. Perrot, Immunodetection by Quartz Crystal Microbalance, Applied Biochemistry and Biotechnology 89 (2000) 139-150.

[42] X. Su, Y.-J. Wu, W. Knoll, Biosens. Bioelectron. 21 (2005) 719-726.

[43] E. L. S. Wong, E. Chow, J. J. Gooding, DNA recognition interfaces: the influence of interfacial design on the efficiency and kinetics of hybridization, Langmuir 21 (2005) 6957-6965. 